\title{
Stock liquidity on the Warsaw Stock Exchange in the 21st century: Time-series and cross-sectional dependencies
}

\author{
Szymon Stereńczak ${ }^{*}$
}

\begin{abstract}
Purpose - The aim of the study is to describe the dynamics of market liquidity and cross-sectional variation in stock liquidity on the Warsaw Stock Exchange in the years 2001-2016.

Design/methodology/approach - To measure stock liquidity three measures have been applied, namely the FHT measure of transaction costs, and the intra-daily version of Amihud's ILLIQ to measure price impact and trading volume to measure trading activity. Measures were computed for the monthly intervals, and to compute market-wide liquidity equally-weighted and volume-weighted averages of liquidity of all listed companies were used.

Findings - The main finding is that market liquidity commoves with the Warsaw Stock Exchange Index (WIG) and the cross-sectional variation of stock liquidity increases with the decrease of market liquidity.

Originality/value - To the best of the author's knowledge, this is the first study on the cross-sectional variation in stock liquidity on the WSE.
\end{abstract}

Keywords: stock liquidity, Warsaw Stock Exchange, liquidity changes

\section{Introduction}

Stock liquidity is an important issue in contemporary finance. Its relevance comes from its effects on asset pricing (see e.g. Amihud, Mendelson, 1986; Amihud, 2002; Pastor, Stambaugh, 2003; Acharya, Pedersen, 2005; Amihud et al., 2015), portfolio allocation (see e.g. Longstaff, 2001; Garleanu, 2009; Gonzalez, Rubio, 2007; Pereira, Zhang, 2010; Garsztka, 2012; Garleanu, Pedersen, 2013) as well as on risk management. In general, liquidity denotes the ability to trade large quantities of a security quickly, at low cost, and without incurring an unfavourable price impact (Pastor, Stambaugh, 2003). The aim of the article is to describe the dynamics of market liquidity and cross-sectional variation in stock liquidity on the Warsaw Stock Exchange in the years 2001-2016.

Since the seminal paper by Amihud and Mendelson (1986) stock liquidity and its effects have been widely investigated on both developed and emerging markets. One may notice the growing body of literature concerning liquidity and its effects on the Warsaw Stock Exchange. Despite the fact that there are studies covering the period after the global

\footnotetext{
* mgr Szymon Stereńczak, Poznań University of Economics and Business, Faculty of Management, al. Niepodległości 10, 61-875 Poznań, e-mail: szymon.sterenczak@ue.poznan.pl.
} 
financial crisis (2007), these studies do not present the dynamics of the liquidity of a market as a whole. Such studies cover the period up to 2011, and there is a lack of research covering the past 5 years.

No less important, since 2012 there have been at least two significant changes which possibly influence liquidity on the Polish stock market. The first of them is the introduction of a new trading system - the Universal Trading Platform - in place of WARSET. As shown by Będowska-Sójka (2017) the introduction of UTP was followed by an increase in liquidity on the Warsaw Stock Exchange. The second change is the reform of Open Pension Funds (OFEs) introduced in February 2014 (Ustawa z 6 grudnia 2013 r.).

Previous studies presenting market-wide liquidity on the Warsaw Stock Exchange do not analyse cross-sectional variation in stock liquidity and changes in this variation over time. To the best of the author's knowledge, this study is the first attempt to describe crosssectional variation in stock liquidity on the Polish capital market. The rest of the paper is organised as follows: Section 1 contains a review of studies analysing the liquidity of the WSE to date, Section 2 presents the sources of data and methodology applied, Sections 3 and 4 are devoted to empirical results and the final section concludes the paper. The study was financed by the National Science Centre, Poland as a research project (2015/19/D/HS4/01950).

\section{Literature overview}

Studies on the level of liquidity on the Warsaw Stock Exchange have become popular in recent years. The first such study, to the best of the author's knowledge, appeared at the beginning of the 21 st century. So far, there have been written at least sixty papers considering this issue. These studies employed different liquidity measures and covered different numbers of stocks and different periods. Several of them are related to liquidity of the market as a whole.

Milo and Wawruszczak (2005) employed Pastor and Stambaugh's (2003) modified measure of liquidity and studied the average liquidity of the Warsaw Stock Exchange between January 1998 and December 2004. The study covered stocks included in the WIG20 index, as they are the most liquid shares on the Polish exchange. They concluded that the liquidity of the surveyed stocks was subject to large fluctuations over time, without specifying any particular trend. Similar research was also conducted by Wawruszczak (2007), but the study period also covered the first half of 2005. The research sample, in addition to shares included in the WIG20, consisted of shares included in other indices, namely Mid-WIG and WIG. The conclusions were very close to those of Milo and Wawruszczak (2005). Large variability in market liquidity was also demonstrated by Kucharski (2009), who employed Pastor and Stambaugh's (2003) pure measure to assess the liquidity of the WSE on the basis of the sixty largest companies from October 2005, to March 2008.

Przybylska-Kapuścińska (2008) analysed the trading volume and turnover ratio of the WSE in comparison to other European stock exchanges in the years 2000-2007. She presented that the trading volume on the Polish stock market decreased from 2000 to 2002, 
and then from 2003 to 2007 systematically increased. In turn, turnover ratio decreased from 2000 to 2004, and increased over the next three years. The author pointed out that in the period analysed, the Polish market developed most strongly among all of the analysed markets. A similar trend was observed by Gruszczyńska-Brożbar (2010), who covered the period from 1996 to 2008. Trading volume was characterized by a slight upward trend in the years 1996-2000, which would decrease in the next two years. The years from 2003 to 2007 were a period of growth in trading volume. This situation reversed in 2008, when volume decreased considerably.

Otola and Grabowska (2012) analysed the liquidity of shares included in the WIG20 index in the years 2005-2009 using three liquidity measures, namely Amihud's (2002) illiquidity (ILLIQ), bid-ask spread and turnover ratio. Amihud's illiquidity ratio was at a relatively high level in 2005, but in 2006 decreased and was quite stable until the second half of 2008. In the second half of 2008 there was a gradual increase in the value of ILLIQ (decrease of liquidity) which continued until the beginning of 2009, when the trend reversed and the values of the illiquidity ratio reached the level they had before the growth. The bidask spread and turnover ratio represented similar patterns as Amihud's ILLIQ.

Porcenaluk (2013) employed a larger number of measures and analysed the liquidity of the Warsaw Stock Exchange on the basis of ninety-two stocks listed in the years 2001-2011. In the period under review, the bid-ask spread was decreasing, except for the years 2003, 2006 and 2011, when a slight increase was recorded. The average number of transactions per session slightly decreased in the years 2001-2004, and then significantly increased, with the exception of the years 2007 and 2010. The average daily volume of shares traded showed an upward trend throughout the whole period, except in 2006 and 2010, and the average volume in PLN decreased only in 2007.

\section{Data and methodology}

To describe the liquidity of the Warsaw Stock Exchange three different measures have been applied. The first measure is a proxy for the proportional bid-ask spread and reflects the trading cost of small transactions. The measure developed by Fong, Holden and Trzcinka (2017) is a simplification of the earlier measure developed by Lesmond, Ogden and Trzcinka (1999). It is based on the same assumption, but is less demanding in terms of computational efforts. This measure does not require the maximization of the likelihood function, but uses a cumulative distribution of a standardised normal distribution and is given by the following formula:

$$
F H T_{m}=2 \sigma_{m} \phi^{-1}\left[\frac{1+\text { Zero }_{m}}{2}\right]
$$

where Zero denotes the proportion of zero-return days in the month $m, \sigma$ is the standard deviation of return, and $\Phi(\cdot)$ is the cumulative distribution of a standardised normal distribution. 
The second applied proxy for liquidity is Amihud's (2002) modified illiquidity measure, which reflects the price impact dimension of liquidity. The modification is that the measure is computed with an intra-daily frequency rather than with a daily frequency. Amihud's illiquidity is given by the following formula:

$$
I L L I Q_{i m}=\frac{1}{N_{i m}} \sum_{t=1}^{N_{i m}} \frac{\left|r_{i m t}\right|}{V o l_{i m t}}
$$

where $N_{i m}$ denotes the number of one-minute intervals with non-zero trading volume of stock $i$ in month $m, r_{i m}$ is the return on stock $i$ in the interval $t$ in month $m$, and $V_{i m t}$ is respective volume in thousands of PLN. While computing the ILLIQ, the "trading at last" phase of the session has been excluded. The last of the liquidity measures employed is monthly trading volume in thousands of PLN, reflecting trading activity.

The study covers all companies listed on the Warsaw Stock Exchange in the years 20012016. Each of the liquidity measures are computed monthly, which gives a time-series of up to 192 monthly values. Market liquidity, measured by FHT and ILLIQ was calculated as the average value of each stock listed in the given month. Market liquidity, measured by trading volume, was computed as a sum of trading volumes of all listed stocks. Because of that in each month the number of companies included in the sample is different, due to new listings and delistings, to ensure comparability, some of the analyses used a sample limited to 47 companies listed across the entire study period.

A considerable issue is the choice of the averaging method in computing market liquidity. Previous studies of the Warsaw Stock Exchange applied an equally-weighted average (Milo, Wawruszczak, 2005; Kucharski, 2009; Otola, Grabowska, 2012) and a volumeweighted average (Porcenaluk, 2013). Using both of these averages seems reasonable. The equally-weighted average reflects the expected stock liquidity on the market, but is not robust to outliers, i.e. the least liquid stocks. The volume-weighted average allows us to assess the amount of realised liquidity costs taking into account the frequency of the trading of each stock. It should be noted that volume-weighted average assigns higher weights to more liquid shares which may lead to an underestimation of market liquidity. In the further analyses, the equally-weighted average and the volume-weighted average will be applied to test for robustness.

The quotation data containing daily open, close, high and low prices and volumes needed to compute FHT and monthly volume, come from the GPWInfoStrefa database. Rates of return are computed daily as simple rates of return. In order to calculate the rates of return needed to estimate the level of liquidity, the prices of shares have first been adjusted for corporate actions, i.e. dividends, splits, reverse-splits and subscription rights. Intra-daily quotations used in computing ILLIQ come from the bossa.pl service. 


\section{Liquidity dynamics on the Warsaw Stock Exchange}

In this section, the dynamic of the liquidity of the Warsaw Stock Exchange is going to be presented and described. The dynamics of the changes in liquidity of the Warsaw Stock Exchange in the years 2001-2016 is plotted in Figure 1. To ensure the readability of the figure, the values of trading volume are marked on the minor axis and values of FHT are multiplied by 10 .

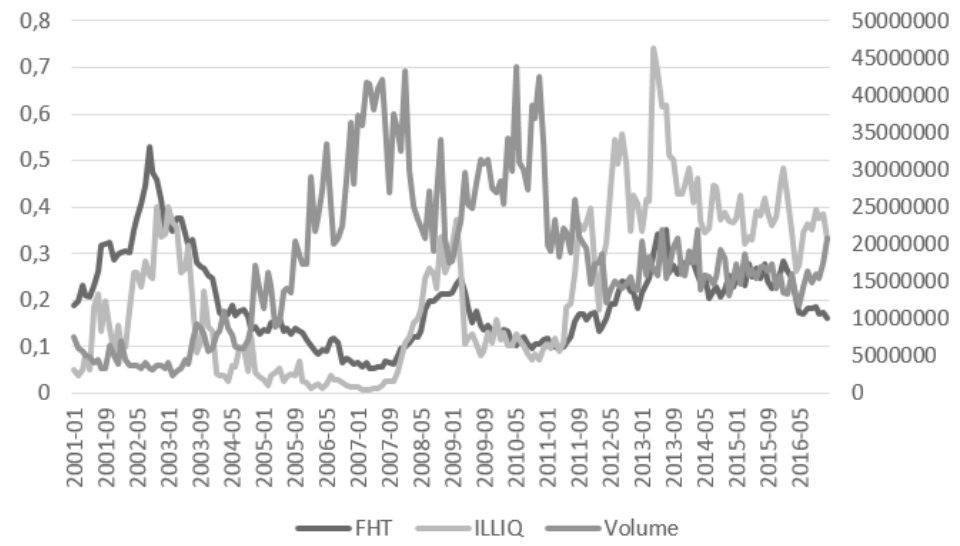

Figure 1. Dynamics of the WSE liquidity

Source: own development.

The liquidity of the Warsaw Stock Exchange decreased (i.e. the values of FHT and ILLIQ increased and trading volume decreased) from early 2001 up till 2002. This is consistent with the findings of previous studies (Przybylska-Kapuścińska, 2008; GruszczyńskaBrożbar, 2010). As the cause of low liquidity in this period, one may indicate the dot-com collapse, which led to a decline on stock exchanges around the world lasting until the last quarter of 2002 (the lowest value of the Nasdaq Composite was recorded on October 9th, $2002-1114.11$ pts). The years from 2000 to 2002 are also the period in which the WSE Index (WIG) was the lowest in the whole analysed period.

After reaching a peak in August 2002 values of market FHT systematically decreased by mid-2007, when the trend was reversed. The drop in liquidity in the second half of 2007 was caused by the subprime crisis whose time frame is set from October 2007 - February 2009 (Olbryś, Majewska, 2014). The end of the crisis is related to the increase of liquidity of the Warsaw Stock Exchange which continued until mid-2011. The next drop in liquidity occurred in the middle of 2011 which was caused by the Eurozone crisis. The introduction of the new trading system (UTP) in April 2013 led to an increase in market liquidity, which is consistent with the findings of Będowska-Sójka (2017). It seems that the reform of Open 
Pension Funds (OFEs) in February 2014 had little impact on the liquidity of the Warsaw Stock Exchange.

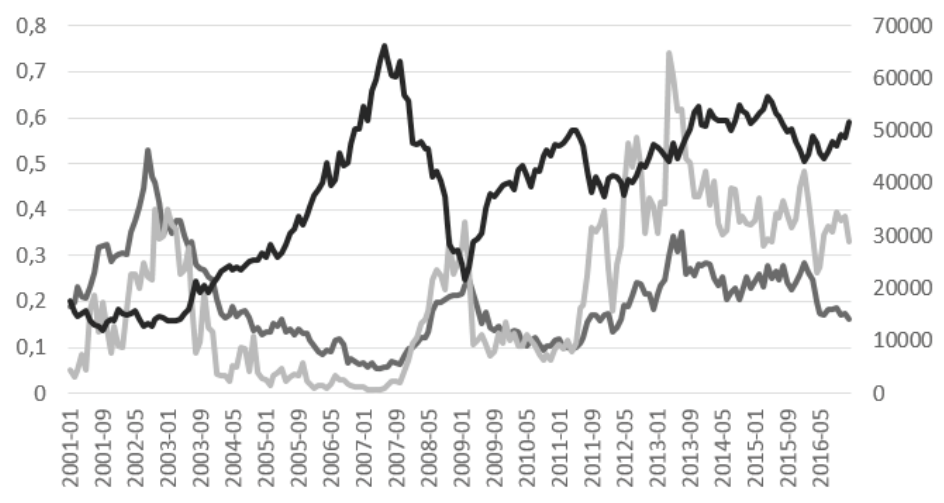

FHT ILLIQ WIG

Figure 2. Comparison of the FHT and ILLIQ with the Warsaw Stock Exchange Index (WIG)

Source: own development.

When analysing changes in liquidity on the Warsaw Stock Exchange, one may conclude that it is strongly related to the economic and stock market situation. This correlation is even more evident if market liquidity is plotted against values of the WIG index, as shown in figures 2 and 3. The values of FHT and ILLIQ have the lowest (highest) values when the WIG is the highest (lowest) and trading volume is the highest (lowest) when the WIG index is the highest (lowest).

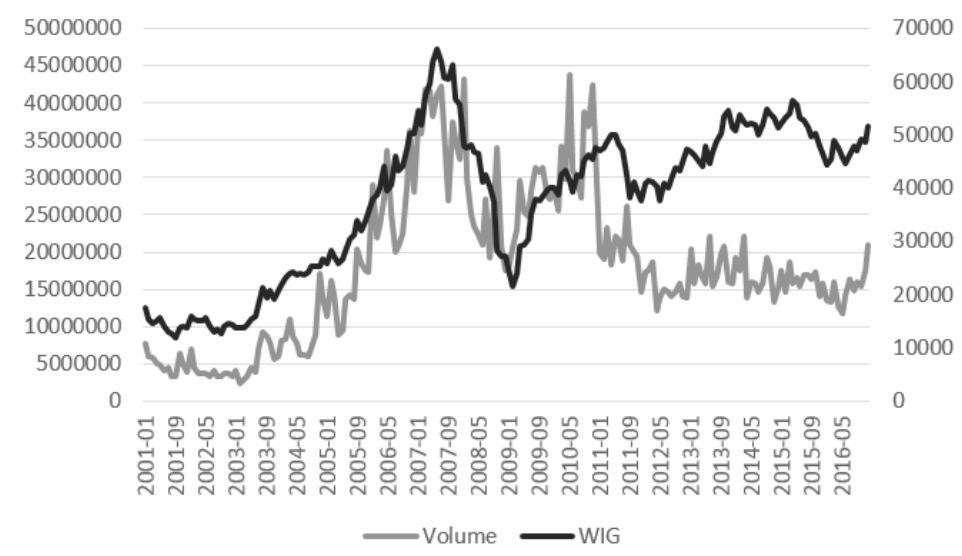

Figure 3. Comparison of trading volume with the Warsaw Stock Exchange Index (WIG)

Source: own development. 
The results of the analyses conducted using volume-weighted market liquidity are similar and they are not reported for brevity. To complete the analysis, in Table 1, Pearson correlation coefficients between liquidity measures and the WIG are presented. The threshold of the significance of the correlation at a confidence level of 0.01 is 0.185 , which means that only the correlation between the volume-weighted ILLIQ for the market and the WIG is insignificantly different from zero.

\section{Table 1}

Pearson correlation between liquidity and the WSE Index

\begin{tabular}{lccccc}
\hline Liquidity measure & FHT $^{\mathrm{EW}}$ & ILLIQ $^{\mathrm{EW}}$ & Volume & FHT $^{\mathrm{VW}}$ & ILLIQ $^{\mathrm{VW}}$ \\
\hline WIG 2001-2016 & -0.5122 & 0.1900 & 0.6793 & -0.5832 & 0.0136 \\
WIG 01.2001-04.2006 & -0.8231 & -0.6878 & 0.9352 & 0.0450 & -0.4583 \\
WIG 05.2006-08.2011 & -0.8789 & -0.7063 & 0.4919 & -0.0479 & -0.4501 \\
WIG 09.2011-12.2016 & 0.4494 & -0.0740 & 0.1333 & -0.6257 & -0.4239 \\
\hline
\end{tabular}

EW and VW in the upper index denotes respectively equally-weighted and volume-weighted market liquidity.

Source: own development.

The correlation between market FHT (both equally and volume weighted) and the WIG index is significantly negative, which indicates that an increase in the WIG is associated with a decrease in FHT (increase of liquidity). An increase in ILLIQ is positively correlated with the WIG which indicates that the higher the WSE Index is, the lower the liquidity. These results are strongly dependent on the latter subperiod (after mid-2011) - in the earlier subperiod this correlation is negative. The correlation between trading volume and the WIG is significantly positive, which means that trading volume increases with the value of the WIG. It should be noted that most of these relations attenuated or even reversed after the Eurozone crisis in 2011. To briefly summarize, the level of market liquidity on the Warsaw Stock Exchange is related to the stock market situation: the better the situation (WIG Index higher) the better market liquidity is.

\section{Cross-sectional variation in liquidity}

Cross-sectional variation in stock liquidity on the Warsaw Stock Exchange was analysed as follows. First, using the data from all companies listed in a given month, standard deviations have been computed for each month of the period 2001-2016. Next, the values of standard deviations have been compared to the average values of liquidity. To avoid biases resulting from the different number of companies included in each month, the analyses have been repeated using data from 47 companies listed across the whole sample period. In figures 4-6 a time-series of standard deviations are plotted and compared with market liquidity in a given period. 


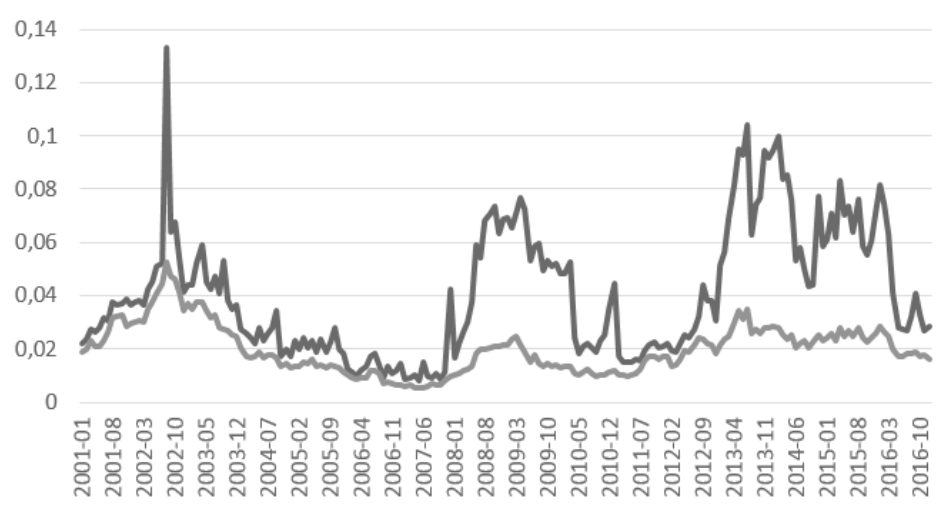

$\longrightarrow$ Std.Dev. $\longrightarrow$ FHT

Figure 4. Cross-sectional variation in the FHT measure of liquidity Source: own development.

One may notice that standard deviations commove with the average value of each measure: when the value of market liquidity measure increases (decreases), the cross-sectional variation of liquidity also increases (decreases). This indicates that an increase in the market liquidity on the Warsaw Stock Exchange is not caused by the even increase in the liquidity of each share but rather the increase in liquidity of more liquid stocks is lower than the increase in liquidity of less liquid ones. Similarly, when market liquidity decreases, this reduction is more severe for less liquid stocks. The results of the analyses conducted on the trimmed sample of companies listed in the whole period are very similar, and hence are omitted for brevity.

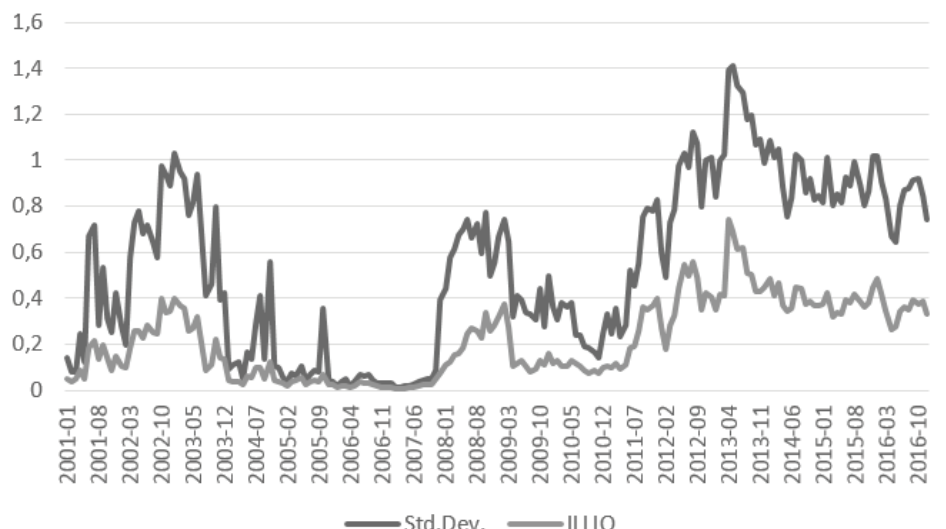

Figure 5. Cross-sectional variation in the ILLIQ measure of liquidity

Source: own development. 


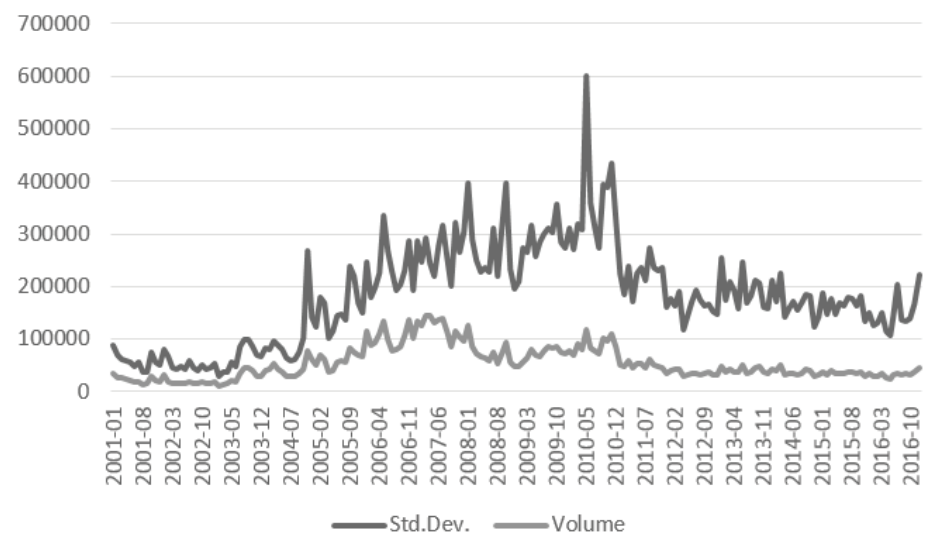

Figure 6. Cross-sectional variation in trading volume

Source: own development.

There are at least two significant increases in the standard deviations of cross-sectional liquidity. One occurs at the turn of 2007 and 2008 when the subprime crisis started. The other one, associated with the Eurozone crisis, is observable in 2011. Surprisingly, the introduction of the new trading system resulted in an increase of cross-sectional variation in liquidity and the reform of Open Pension Funds (OFEs) caused a slight decrease in the crosssectional variation in stock liquidity.

To formally confirm the existence of the dependencies presented on figures $4-6$, a correlation analysis has been conducted. Table 2 presents the results of Pearson correlation coefficients between average liquidity and standard deviation for each liquidity measure using the whole sample and the same for the trimmed sample of 47 stocks listed on the WSE in the whole period.

Table 2

Pearson correlation between market liquidity and cross-sectional variation in liquidity

\begin{tabular}{llllll}
\hline Liquidity measure & FHT $^{\mathrm{EW}}$ & ILLIQ $^{\mathrm{EW}}$ & Volume & FHT $^{\mathrm{VW}}$ & ILLIQ $^{\mathrm{VW}}$ \\
\hline Std.Dev. - whole sample & 0.6830 & 0.9701 & 0.9310 & 0.4678 & 0.9255 \\
Std.Dev. - trimmed sample & 0.8487 & 0.9882 & 0.9661 & 0.6098 & 0.5676 \\
\hline
\end{tabular}

EW and VW in the upper index denotes respectively equally-weighted and volume-weighted market liquidity.

Source: own development.

Again the threshold of the significance of the correlation at a confidence level of 0.01 is 0.185 , which means that all the correlation coefficients presented are significantly positive. The presented results confirm that the growth in liquidity measure is associated with the growth of its cross-sectional variance. Thus, it can be stated that less liquid companies 
gain more (lose more) from the increase (decrease) in market liquidity than more liquid ones. This is consistent with Liu (2006), Brunnermeier and Pedersen (2009) and Amihud and Mendelson (2008) who claim that less liquid shares have higher volatility of liquidity over time. As mentioned by Amihud and Mendelson (2008), this is due to the fact that in the case of a drop in the level of liquidity, investors shift from less liquid to more liquid shares, exacerbating the decline in the liquidity of less liquid stocks. This phenomenon is interpreted as the "flight-to-liquidity".

\section{Concluding remarks}

The aim of the paper was to describe the changes in market liquidity and cross-sectional variation in stock liquidity on the Warsaw Stock Exchange in the years 2001-2016. Previous studies conducted using the data on the companies listed on the Polish stock market cover the period up to 2011 and after that, at least two significant changes in the trading environment appeared, namely the introduction of the new trading system (UTP) in April 2013 and the reform of Open Pension Funds in February 2014. Equally important, previous studies have not considered cross-sectional variation and its dynamics.

The results of the analyses conducted are as follows. Market liquidity changes are associated with changes in market conditions: liquidity decreases in times of market declines and improves in times of bull markets. This is consistent with the intuition that in periods of market decline, investors withdraw from the market, which in turn leads to greater difficulties in finding transaction counterparts. This situation is the cause of reduced liquidity. However, the dependencies indicated attenuated or even reversed (depending on the applied liquidity measure) after the Eurozone crisis in 2011.

Cross-sectional variations in stock liquidity on the Warsaw stock Exchange were also subject to change over time. Plotting the values of cross-sectional standard deviations with average values of liquidity measures in each month allowed us to notice that the former increases with an increase of the latter. Thus, stock liquidity changes in such a way that in the case of increased market liquidity, highly liquid shares gain less from this increase than low liquid shares. However, in the case of decreased market liquidity, the liquidity of more liquid shares decreases less than the liquidity of less liquid ones. This leads to the conclusion that on the Warsaw Stock Exchange liquidity volatility over time of low liquid shares is higher than the corresponding volatility of high liquid shares.

The author is conscious that these analyses have numerous limitations, including a limited set of liquidity measures employed, and a limited number of research methods applied. This study might be developed further by investigating the dependencies present, using a different set of liquidity measures, e.g. high-low spread estimator (Corwin, Schultz, 2012), Roll's (1984) effective spread estimator, the basic version of Amihud's (2002) measure, round-trip transaction cost estimator (Lesmond, Ogden, Trzcinka, 1999), and other ones, 
too. One might also apply different methods, including testing for differences in liquidity volatility over high and low liquid stocks.

\section{References}

Acharya, V.V., Pedersen, L.H. (2005). Asset pricing with liquidity risk. Journal of Financial Economics, 2 (77), $375-410$.

Amihud, Y. (2002). Illiquidity and stock returns. Cross-section and time-series effects. Journal of Financial Markets, 1 (5), 31-56.

Amihud, Y., Hameed, A., Kang, W., Zhang, H. (2015). Stock liquidity and the cost of equity capital in global markets. Journal of Applied Corporate Finance, 4 (27), 68-74.

Amihud, Y., Mendelson, H. (1986). Asset pricing and the bid-ask spread. Journal of Financial Economics, 2 (17), 223-249.

Amihud, Y., Mendelson, H. (2008). Liquidity, the value of a firm, and corporate finance. Journal of Applied Corporate Finance, 2 (20), 32-45.

Będowska-Sójka, B. (2017). The comparison of liquidity measures - the evidence from the Warsaw Stock Exchange (Working paper). DOI: 10.13140/RG.2.2.24519.29608.

Brunnermeier, M.K., Pedersen, L.H. (2009). Market liquidity and funding liquidity. The Review of Financial Studies, 6 (22), 2201-2238.

Corwin, S.A., Schultz, P. (2012). A simple way to estimate bid-ask spreads from daily high and low prices. The Journal of Finance, 2 (67), 719-760.

Fong, K.Y.L., Holden, C.W., Trzcinka, C.A. (2017). What are the best liquidity proxies for global research?. Review of Finance, 5 (21), 1355-1401.

Gârleanu, N. (2009). Portfolio choice and pricing in illiquid markets. Journal of Economic Theory, 2 (144), $532-564$.

Gârleanu, N., Pedersen, L.H. (2013). Dynamic trading with predictable returns and transaction costs. The Journal of Finance, 6 (68), 2309-2340.

Garsztka, P. (2012). Konstrukcja portfela papierów wartościowych z uwzględnieniem płynności walorów. Zeszyty Naukowe Uniwersytetu Ekonomicznego w Poznaniu, 242, 69-82.

Gonzalez, A., Rubio, G. (2011). Portfolio choice and the effects of liquidity. Journal of the Spanish Economic Association, 1 (2), 53-74.

Gruszczyńska-Brożbar, E. (2010). Płynność jako wyznacznik rozwoju Giełdy Papierów Wartościowych w Warszawie w latach 1996-2008. Ruch Prawniczy, Ekonomiczny i Socjologiczny, 1, 137-149.

Kucharski, A. (2009). Badanie szerokości rynku akcji notowanych na polskiej giełdzie. Prace Naukowe Uniwersytetu Ekonomicznego we Wrocławiu, 60, 235-241.

Lesmond, D.A., Ogden, J.P., Trzcinka, C.A. (1999). A new estimate of transaction costs. Review of Financial Studies, 5 (12), 1113-1141.

Liu, W. (2006). A liquidity-augmented capital asset pricing model. Journal of Financial Economics, 3 (82), 631-671.

Longstaff, F. (2001). Optimal portfolio choice and the valuation of illiquid shares. Review of Financial Studies, 2 (14), 407-431.

Milo, W., Wawruszczak, M. (2005). Analiza płynności finansowej GPW w Warszawie. Prace Naukowe Akademii Ekonomicznej we Wroctawiu, 1088, 27-35.

Olbryś, J., Majewska, E. (2014). Direct identification of crisis periods on the CEE stock markets: The influence of the 2007 U.S. Subprime Crisis. Procedia Economics and Finance, 14, 461-470.

Otola, I., Grabowska, M. (2012). Empiryczna analiza płynności rynku akcji w oparciu o wybrane mierniki. Acta Universitatis Lodziensis. Folia Oeconomica, 262, 125-137.

Pastor, L., Stambaugh, R.F. (2003). Liquidity risk and expected stock returns. Journal of Political Economy, 3 (111), $642-685$.

Pereira, J.P., Zhang, H.H. (2010). Stock returns and the volatility of liquidity. The Journal of Financial and Quantitative Analysis, 4 (45), 1077-1110.

Porcenaluk, P. (2013). Analiza wybranych miar ryzyka płynności dla akcji notowanych na GPW w Warszawie. Prace Naukowe Uniwersytetu Ekonomicznego we Wrocławiu, 323, 289-297.

Przybylska-Kapuścińska, W. (2008). Rozwój polskiego rynku giełdowego na tle sytuacji giełd europejskich w XXI wieku. Roczniki Ekonomiczne Kujawsko-Pomorskiej Szkoły Wyższej w Bydgoszczy, 1, 117-137. 
Roll, R. (1984). A simple implicit measure of the effective bid-ask spread in an efficient market. The Journal of Finance, 4 (39), 1127-1139.

Ustawa z dnia 6 grudnia 2013 r. o zmianie niektórych ustaw w związku z określeniem zasad wypłaty emerytur ze środków zgromadzonych w otwartych funduszach emerytalnych (Dz.U. 2013, poz. 1717).

Wawruszczak, M. (2007). O płynności finansowej Giełdy Papierów Wartościowych w Warszawie. Zeszyty Naukowe Uniwersytetu Szczecińskiego. Finanse, Rynki Finansowe, Ubezpieczenia, 6, 487-494.

\section{PLYNNOŚĆ AKCJI NA GIELDZIE PAPIERÓW WARTOŚCIOWYCH W WARSZAWIE W XXI WIEKU: ZALEŻNOŚCI W CZASIE I W PRZEKROJU}

Streszczenie: $\mathrm{Cel}$ - Celem badania jest opisanie zmian płynności rynku oraz przekrojowego zróżnicowania płynności akcji na Giełdzie Papierów Wartościowych w Warszawie w latach 2001-2016.

Metodologia badania - Do pomiaru płynności wykorzystano trzy miary płynności: miara kosztów transakcyjnych - FHT, śróddzienna wersja miary Amihuda (ILLIQ) oraz wartość obrotów. Miary obliczano dla okresów miesięcznych, natomiast jako miarę płynności całego rynku wykorzystano średnią arytmetyczną oraz średnią ważoną obrotami płynności wszystkich akcji na rynku.

Wynik - Wykazano, że płynność rynku zmienia się w takim samym kierunku jak wartości indeksu WIG, natomiast przekrojowe zróżnicowanie płynności akcji wzrasta wraz ze zmniejszeniem płynności rynku.

Oryginalność/wartość - Według najlepszej wiedzy autora, jest to pierwsze badanie przekrojowego zróżnicowania płynności akcji na GPW w Warszawie.

Słowa kluczowe: płynność akcji, GPW w Warszawie, zmiany płynności

\section{Citation}

Stereńczak, S. (2018). Stock liquidity on the Warsaw Stock Exchange in the 21st century: Time-series and crosssectional dependencies. Finanse, Rynki Finansowe, Ubezpieczenia, 1 (91), 281-292. DOI: 10.18276/ frfu.2018.91-23. 